\title{
Testing the Regumate Product in Association with Other Hormonal Products for Oestrus Synchronization in Gilts
}

\author{
Liviu BOGDAN, Anamaria BLAGA PETREAN*, Sanda ANDREI, Nicodim FIŢ, Mihai CENARIU, Ioan PAȘCA, \\ George NADĂȘ, Rebeka HŐGYE, Sidonia BOGDAN
}

Faculty of Veterinary Medicine, University of Agricultural Sciences and Veterinary Medicine, Mănăștur street, no. 3-5, Cluj-Napoca, Romania

*corresponding author: anamariapetrean@yahoo.com

Bulletin UASVM Veterinary Medicine 74(2)/2017

Print ISSN 1843-5270; Electronic ISSN 1843-5378

doi:10.15835/buasvmcn-vm:0042

\begin{abstract}
The aim of this study was to evaluate the effect of Regumate ${ }^{\circledR}$ product in association with other hormonal products as a method for oestrus synchronization in gilts. The study was carried out between October 2016 - March 2017 in a private unit in Cluj County, and involved 16 gilts, 8 months of age. The synthetic progesterone Regumate was fed daily at $20 \mathrm{mg}$ Altrenogest/gilt for 18 days. For all animals, 24 hours after cessation of progesterone treatment a PMSG hormone (Folligon) was administered (500 IU/gilt). After a rest period (48 hours) gilts received one injections of hCG hormone (Chorulon), $500 \mathrm{IU} /$ gilt. Gilts were checked for oestrus twice daily and were artificially inseminated. Oestrus occurred on average 5 days after completion of treatment. All gilts expressed signs of oestrus between 24 and 30 hours with a mean value of 28.37 hours. Pregnancy rate was $75 \%$ after second insemination. The mean value of farrowed piglets was 10.16 and the average number of weaned piglets in was 9.58. Altrenogest, the active ingredient in Regumate $®$ is effective for regulating the oestrus of gilts in commercial pig farms.
\end{abstract}

Keywords: oestrus, gilts, pregnancy, Regumate, synchronization

\section{INTRODUCTION}

Altrenogest is a synthetic steroid with progestagenic activity that postpones the onset of the follicular phase. Therefore, it is used to synchronize the cycle of sows and gilts. For synchronization of a group of gilts with an unknown stage of the cycle, the product (Regumate) should be fed for a period of 18 days. It has been claimed that, after synchronization with altrenogest, ovulation rate of gilts is improved (Knight et al., 1976; MartinatBotte' et al., 1995) as well as subsequent litter size and farrowing rate (Varley 1983; Martinat-Botte' et al., 1990).

In a number of research studies, altrenogest has been used to synchronize oestrus in randomly cycling gilts (Webel and Day, 1982; Day, 1984, Gordon, 1997). To summarize a number of studies, daily feeding of altrenogest (12.5 to 15 $\mathrm{mg}$ /day) for 14 to 18 days, synchronized oestrus in approximately $90 \%$ of treated gilts. The onset of oestrus after withdrawal of altrenogest was reported as 4 to 10 days with most gilt in oestrus between 5 and 7 days.

In experiments conducted at the Tidewater Agricultural Research and Extension Center (TAREC) in Suffolk altrenogest was used to successfully synchronize oestrus in gilts (Estienne et al., 2001; Estienne and Harper, 2002; Horsley et al., 2004). For example, 86 randomly-cycling, crossbred gilts were given feed containing altrenogest (15 mg/day) for 18 days. A large proportion of the gilts displayed oestrus within 7 days after withdrawal of altrenogest. After oestrus, a small group of altrenogest-treated gilts was mated via artificial insemination. At day 30 post- 
mating, $88.5 \%$ of the gilts $(23 / 26)$ were confirmed pregnant.

\section{MATERIALS AND METHODS}

The study was carried out between October 2016 - March 2017 in a private unit in Cluj County, and involved 16 gilts, 8 months of age. The synthetic progesterone Regumate was fed daily at $20 \mathrm{mg}$ Altrenogest/gilt for 18 days. For all animals included in our investigations, 24 hours after cessation of progesterone treatment a PMSG hormone (Folligon) was administered (500 IU/ gilt). After a rest period (48 hours) gilts received one injections of hCG hormone (Chorulon), 500 IU/gilt.

Semen was collected twice per week and volume, color and motility were evaluated. The semen was diluted in Merck III extender (Minitube), packaged in $100 \mathrm{ml}$ bottles with $4.0 \times 10^{9}$ spermatozoa. Diluted semen was storaged at $18{ }^{\circ} \mathrm{C}$. The extension process was performed in a warm room with clean and sterile equipment. The extender was added to the semen, and cold shock was avoided (the temperature was diminish gradually). Each dose contained 3 billion spermatozoa in $80-100 \mathrm{ml}$.

Gilts were checked for oestrus twice daily and were artificially inseminated. Gilts received first artificial insemination (AI) 12 hours after estrous was detected and second AI 21 days. Pregnancy rate was determinate at 30 days after insemination by using a portable ultrasound. All pregnant gilts were kept under observation and a week before parturition was moved in individual boxes.

The following parameters were investigated: interval of oestrus onset, oestrus duration, pregnancy rate, total piglets born per litter, weaned piglets.

\section{RESULTS AND DISCUSSIONS}

The onset of synchronized oestrus was calculated from the time of administration of hormone to the time of first appearance of oestrus symptoms. The mean interval between Regumate treatment and the onset of oestrus was $5 \pm 1.03$ days ranging from 3-7 days (Table 1). Similar results were recorded for gilts treated with the same dose of altrenogest (Davis et al., 1976; Knight et al., 1976; Webel and Scheid, 1980; Dimitrov et al., 2010).
All gilts (100\%) expressed signs of oestrus between 24 and 30 hours with a mean value of $28.37 \pm 2.22$ hours (table 1). Davis (2008) reported that $85 \%$ or more cycling gilts have expressed oestrus within 4 to 10 days after last treatment with altrenogest at the dose rate of 15 mg daily for 14 days. Stancic et al. (2014) reported that 90,40 and $65 \%$ of the gilts exhibited oestrus which were treated with $20 \mathrm{mg}$ of Altrenogest for 18 days, two i.m injections of $5 \mathrm{mg}$ of Dinoprost (Dynolitic®) and single injection of 1,000 IU eCG (Folligon), respectively.

A longer duration of oestrus than the present study was reported by Noguchi et al. (2010) and Konch et al. (2012).

Tab.1. Fertility parameters recorded

\begin{tabular}{lc}
\hline \multicolumn{1}{c}{ Parameters } & Values \\
\hline Estrus response rate (\%) & $100(16 / 16)$ \\
\hline Onset of estrus (days) & $5 \pm 1.03$ \\
\hline Duration of estrus (h) & $28.37 \pm 2.22$ \\
\hline Conception rate (\%) & $75(12 / 16)$ \\
\hline Farrowed piglets (n) & $10.16 \pm 1.89$ \\
\hline Weaned piglets (n) & $9.58 \pm 1.62$ \\
\hline
\end{tabular}

The percentage of oestrus return was $50 \%$ (8 gilts) after first artificial insemination. In the present experiment the conception rate after second artificial insemination was $75 \%$, which was similar to the observations of Johnson et al. (1988) and Johnson (1998). Higher conception rate than that of the present study was found by Ronald et al. (2013), Behan and Watson (2006), Ugwu and Igboeli (2009) and Patra et al. (2016).

The mean value of farrowed piglets was $10.16 \pm 1.23$ and the average number of weaned piglets in was 9.58 \pm 1.11 . Boyer and Almond (2014) have reported that the mean value for the piglets born alive was between $10.06 \pm 0.08$ and $10.33 \pm 0.06$. Same authors revealed a mean value of weaned piglets between $9.78 \pm 0.08-10.31 \pm 0.03$. The results obtained by Dimitriv et al. (2010), were much better, yielding 12.6 viable piglets, while Rensis et al. (2015), in the experimental group treated for 18 days with Altrenogest, obtained 13.3 piglets, of which 12.2 piglets were weaned. 


\section{CONCLUSIONS}

It is possible to conclude that altrenogest treatment is an efficient method for oestrus synchronization in gilts from commercial pig farms, resulting in heavier and more uniform litters.

\section{REFERENCES}

1. Boyer PE, Almond GW (2014). Use of altrenogest at weaning in primiparous sows, J Swine health Prod., 22(3):134-137.

2. Davis DL, Killian DB, Day BN (1976). Control of estrus in gilts with compound A-35957. Journal of Animal Science, $42,1358$.

3. Davis LD (2008). Using Regumate to Control Estrus in Swine. Swine Day Report of Progress 940, Kansas State University, USA, pp. 11-15.

4. Day BN (1984). Estrous cycle regulation. Proceedings of the 10th International Congress Animal Reproduction and AI (Urbana) IV, pp. 1-8.

5. Dimitrov S, Bonev G, Taseva H (2010). Synchronization of estrous in gilts with Altrenogest, Agricultural Science and Technology, 2(1): 3 - 5.

6. Estienne MJ and Harper AF (2002). Case study: Synchronization of estrus and fertility in gilts administered P.G. 600 after treatment with Regu-mate for 14 or 18 days. The Professional Animal Scientist, 18:158-161.

7. Estienne MJ, Harper AF, Horsley BR, Estienne CE, Knight JW (2001). Effects of P.G. 600 on the onset of estrus and ovulation rate in gilts treated with Regu-mate. Journal of Animal Science, 79:2757-2761.

8. Gordon I (1997). Controlled Reproduction in Pigs. CAB International, Wallingford, UK.

9. Horsley BR, Estienne MJ, Purcell SH, Baitis HK, Beal WE, Harper AF, Knight JW (2005). Effect of P.G. 600 on the timing of ovulation in gilts treated with altrenogest. Journal of Animal Science, 83: 1690-1695.

10. Johnson LA (1998). Current developments in swine semen: preservations, artificial insemination and sperm sexing. In: Proceedings of the $15^{\text {th }}$ International Pig Vet Science Congress 1: 225-229.

11. Johnson LA, Aalbers JG, Grooten HJG (1988). Artificial insemination of swine: Fecundity of boar semen stored in Beltsville TS BTS, Modified Modena MM, or MR-A and inseminated on one, thee and four days after collection. Zuchthygiene, 23: 49-55.

12. Knight JW, Davis DL, Day BN (1976). Estrus synchronization in gilts with progestogen. Journal of Animal Science, 42(Suppl. 1):1358-1359 (Abstr.).

13. Konch H, Dutta A, Baruah KK, Sinha S (2012). Synchronization of estrus in cyclic Hampshire gilts. Indian Veterinary Journal, 89(5): 47- 48.

14. Martinat-Botte F, Bariteau F, Forgerit Y, Macar C, Terqui M, Signoret JP (1990). Control of oestrus in gilts. II Synchronisation of oestrus with a progstagen, altrenogest (Regumate): effect on fertility and litter size. Anim Reprod Sci, 22, 227-233.

15. Martinat-Botte F, Bariteau F, Forgerit Y, Macar C, Poirier P, Terqui M (1995): Synchronisation of oestrus in gilts with altrenogest: effects on ovulation rate and foetal survival. Anim Reprod Sci, 39, 267-274.

16. Noguchi M, Yoshioko K, Suzuki C, Ari S, Itoh S, Wada Y (2010). Estrus synchronization with pseudo pregnant gilts induced by a single treatment of estradiol dipropionate. Journal of Reproduction and Development, 56(4): 421427.

17. Rensis de F, Mazzoni C, Saleri R, Techakumphu M, Kirkwood RN (2015). Effect of short (10-or 12- days) or standard (14- or 18-days) periods of estrus suppression with allyl trenbolone on estrus synchronization and fertility in pubertal gilts, Journal of Swine Health and Production, Volume 23, number 2

18. Stancic I, Radovic I, Gvozdic D, Savic B, Stancic B, Bosnjak D (2015). Estrus Induction in Sexually Mature Gilts with Different Hormonal Treatments. Proceedings of the International Symposium on Animal Science 2014, September 2014, Belgrade-Zemun, 37-42.

19. Varley MA (1983). The regulation of oestrus cycles in groups of post-pubertal female pigs using allyl-trenbolone. Anim Prod, 36:211-215.

20. Webel SK, Scheid JP (1980). Estrus control in pigs U.S. field trial results with a new progestin compound RU-2267Regumate. Proceeding of International Pig Veterinary Society Congress, p. 49.

21. Webel SK and Day BN (1982). The control of ovulation. In: D.J.A. Cole and G.R. Foxcroft (Eds.) Control of Pig Reproduction. Butterworths, London. pp. 197-210. 